УДК 640.4-025.12:543.927:005.591.6

DOI: 10.15673/fie.v13i3.2135

Ряшко Г.М.

кандидат технічних наук, доцент кафедра готельно-ресторанного бізнесу

E-mail: rina257@gmail.com

ORCID: 0000-0002-6237-7263

Новічкова Т.П.

кандидат технічних наук, доцент кафедра готельно-ресторанного бізнесу

E-mail: tamarakoled@gmail.com

ORCID ID: 0000-0001-6133-9882
Асауленко Н.В.

старший викладач

кафредра готельно-ресторанного бізнесу

E-mail: nataliya.asaulenko@ukr.net

ORCID: 0000-0001-7057-4614

Новічков В.К.

кандидат географічних наук, доцент кафедра готельно-ресторанного бізнесу

Одеська національна академія харчових технологій вул. Канатна 112, м. Одеса, Україна, 65039

E-mail: vicnov@ukr.net

ORCID ID: 0000-0001-9720-8163

\title{
ПРОЕКТУВАННЯ ПОСЛУГ ДЕГУСТАЦІЙНИХ ЗАЛІВ ЯК СТРАТЕГІЧНИЙ ВЕКТОР РОЗВИТКУ СЕРВІСУ В ІНДУСТРІЇ ГОСТИННОСТІ
}

Стаття розглядає підходи пошуку інновацій для створення дегустаційного залу та проектування асортименту додаткових послуг на його основі. Одеській регіон характеризується активним розвитком виноробної промисловості, в тому числі збільшенням кількості гаражних виробництв. Незважаючи на те, що збільшується інтерес до винного туризму, населення не має достатньої інформації щодо більшості з одеських виробників. Для порівняння якості вина різних виробників необхідно проводити моносортові дегустації, які не можливі в дегустаційних залах, розташованих на виноробних виробництвах. Проектування асортименту послуг дегустаційного залу у складі підприємства індустрії гостинності, доцільно проводити з використанням анкетування, контекстного аналізу відгуків та мозкового штурму, враховуючи ресурси закладу готельно-ресторанного бізнесу. Такі дослідження дозволяють обрати асортимент сервісних послуг, що можуть впроваджуватись в роботу конкретного закладу та приносити максимальний прибуток. В якості прикладу наведено дослідження щодо проектування додаткових послуг при створенні дегустаційного залу в готелі «Атлантік».

Ключові слова: проектування, сервіс, інновації, дегустаційний зал, індустрія гостинності, заклади готельно-ресторанного господарства.

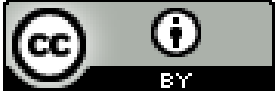

This work is licensed under a Creative Commons Attribution 4.0 International License http://creativecommons.org/licenses/by/4.0/
Постановка проблеми та її зв'язок з важливими науковими та практичними завданнями. 3 розвитком туризму в світі змінюються і вподобання певного сегменту туристів, розвиваються нові направлення туризму. Споживачам важливо отримати не тільки якісний відпочинок та розваги, а й отримувати нові враження та знання. Турист стає більш досвідченим. Йому цікаво пізнавати історичні факти, культуру, певні особливості регіону та інше. Україна також не залишилась осторонь цієї тенденції. В останні роки в Україні стрімко розвивається культура споживання вина. Населення стає більш досвідченим в якості вина, еногастрономії та його виробництві. Це дає поштовх для розвитку якісного винного та гастрономічний туризму, з'являються невеликі виробництва вина, так звані «гаражні вина», сироварні з дегустаційними залами, наприклад Свропейська сироварня в Шабо, що на Одещині. Також останнім часом в закладах ресторанного господарства зростає попит на послуги сомельє, не тільки винного призначення, а й різних напрямків гастрономії. Тому такі вподобання туристів сприяють розширенню асортименту сервісних послуг на підприємствах індустрії гостинності. А саме почали створюватись дегустаційні зали окремо від виробничих підприємств, як самостійна організація. Дегустація гастрономічних продуктів має особливу привабливість для туристів та $є$ перспективним вектором розвитку сервісу в індустрії гостинності. Але, на теперішній час немає наявних практичних рекомендацій щодо проектування послуг для дегустаційних залів та їх організації обслуговування у складі підприємств індустрії гостинності.

Аналіз останніх публікацій по проблемі. Проблемою проектування та оптимізації асортименту послуг на підприємствах сфери гостинності займалось багато іноземних науковців - R. C. Ford, M. C. Sturman, C. P. Heaton, P. Kotler, K. M. Bretthauer, R. C. Ford, C. P. Heaton, S. W. Brown та українських - O.O. Романенко, О. М. Шаповалова, С. С. Козьякова, А.В. Троян. В своїх працях вони надавали загальні 
рекомендації щодо розробки асортиментної політики підприємства. Маркетингові дослідження щодо проектування асортименту послуг саме для дегустаційних залів займався ряд зарубіжних авторів - Marin Shapiro, Miguel I. Gomez, Matti Haverila, Kai Haverila, Mehak Aror. Вони приділяли увагу маркетинговим дослідженням щодо задоволення клієнтів роботою дегустаційних залів. Але український ринок має свої особливості і вони не в повній мірі відображаються в роботах перелічених авторів. Тому $\epsilon$ необхідність розробити рекомендації щодо проектування асортименту послуг для дегустаційних залів, розташованих у складі підприємств індустрії гостинності на території України.

Формулювання цілей дослідження. Актуальність теми статті обумовлена пошуком стратегічного вектору розвитку сервісу закладами індустрії гостинності. Вони перебувають в постійному пошуку нових сервісних інновацій, що можуть підвищити їх конкурентоспроможність, привернути до себе нову цільову аудиторію - споживачів, що зацікавлені в гастрономічному туризмі. Таким чином, метою статті $\epsilon$ визначення наукових методик, що можна використовувати для проектування асортименту послуг дегустаційного залу, розташованого на підприємстві індустрії гостинності для розвитку сервісу. Для досягнення поставленої мети передбачається вирішення наступних задач: аналіз та узагальнення інформації щодо питань проектування асортименту послуг в дегустаційному залі; огляд наукових методик, що можна використовувати для визначення асортименту послуг в дегустаційному залі підприємства індустрії гостинності; проведення досліджень на основі обраних методик; обробка отриманої інформації та визначення асортименту послуг на прикладі дегустаційного залу при готельно-ресторанному комплексі «Атлантік» в рамках розвитку винного туризму в Одеській області; надання рекомендацій щодо проектування асортименту послуг для дегустаційних залів, розташованих на підприємствах індустрії гостинності.

Виклад основних результатів та їх обгрунтування. Зростання популярності гастрономічного туризму призводить до розширення мережі дегустаційних залів. Раніше вони створювались в основному, як структурний підрозділ виноробних виробництв. На даний момент можна виділити декілька тенденцій щодо розвитку дегустаційних залів. По-перше, розширилось кількість продукції, для якої створюються дегустаційні зали. Окрім виноробних виробництв, дегустаційні зали відкриваються на підприємствах, що виробляють пиво, коньяк, віскі, сир, бринза, кава, мед i, навіть, хліб. По-друге, дегустаційні зали почали створювати окремо від виробничих підприємств. Дуже часто вони створюються на території підприємств сфери гостинності - при ресторанах та готелях [11]. Часто дегустації організовують прямо в залі ресторану.

Дегустаційні зали, створені не на основі певного виробництва можуть бути більш привабливими для споживачів, оскільки в одному дегустаційному сеті може суміщатись продукція різних виробників.
Наприклад, можна проводити моносортові дегустації, коли порівнюються однакові продукти різних виробників. Таким чином, споживач має можливість продегустувати та порівняти між собою продукцію, що виготовлена різними виробниками. Крім того, такі дегустаційні зали дають змогу проводити окрім монопродуктових дегустацій, ще й комплексні, що об'єднують в собі декілька продуктів, наприклад, сети, що поєднують в собі вина та сири [12].

Таким чином, дегустаційний зал, створений окремо від виробництва має ряд переваг. Такий дегустаційний зал стає майданчиком для просування різних торгових марок декількох видів продукції. Невеликі крафтові виробництва не мають можливості створювати свої фірмові магазини, тому дегустаційний зал може стати для них додатковою точкою прямих продажів споживачам. Це дає можливість уникати посередників та отримувати більше прибутків, ніж від оптових продажів.

Створення дегустаційного залу на території закладів готельно-ресторанного господарства дозволяє розширювати асортимент додаткових послуг, підвищувати конкурентоспроможність, отримувати додатковий прибуток для підприємств. Відпочиваючи в готелі, гості можуть замовити проведення дегустації без потреби залишати готель. Проведена за правилами дегустація підвищує культуру споживання, збагачує знаннями щодо дегустаційного продукту та покращує культурний рівень учасників дегустації. Крім того, поява дегустаційних залів знайомить споживачів $з$ регіональними виробниками та підвищує туристичну привабливість регіону.

При створенні дегустаційного залу на території готелю, що розташований в м. Одеса, на нашу думку, необхідно спиратись на виноробну промисловість Одеської області, що активно розвивається на даний момент. Окрім великих виробників на ринку присутні у великий кількості крафтові, так звані, гаражні виробники, що випускають високоякісний продукт, але через невеликі об'єми виробництва придбати цю продукцію досить складно. До великих виноробних підприємств одеської області також належать наступні виробники: «Французький бульвар», «Шабо», Одеський завод шампанських вин, Ізмаїльський виноробний завод, Болградський виноробний завод, «Вінхол Оксамитне», «Колоніст». Серед крафтових виробників вина Одеської області можна відзначити таких виноробів, як Валерій Петров (с. Струмок Татарбунарського району), Кристоф де Лакарен (с. Шабо), Мар'ян Шевченко (с. Біляєвка), Валерій Польшаков, Василь Живора та Іван Дімов (м. Ізмаїл), Станіслав Рожков (м. Кілія), Кирчиков Іван та Валерій Желясков (с. Криничне Болградського району), Шаповалов Олександр (м. Чорноморськ), Димура Олександр (м. Одеса), Георгієв Георгій (Саратський район). Вино цих виноробів займало призові місця на різноманітних конкурсах вина. Також серед невеликих виробників можна відзначити виноробню Дона Алехандро та центр етнографічного, сільського і зеленого туризму та сімейного відпочинку «Фрумушика-Нова», вина яких також мають багато прихильників. 
Таким чином, можна зробити висновок, що одеський регіон має досить високе число виноробних підприємств, продукція яких може бути використана при створенні дегустаційного залу з одеськими винами.

Створення дегустаційного залу на підприємстві індустрії гостинності повинно розпочинатись 3 визначення асортименту послуг та сервісного обслуговування в ньому.
Для дослідження уподобань потенційних відвідувачів винного дегустаційного залу при готелі «Атлантік» було обрано метод анкетування. Анкетування проводилось он-лайн завдяки формі, створеній на основі «Google Диск». В опитуванні прийняло участь 168 чоловік.

Згідно анкетуванню більшість опитуваних (39,3 \%) віддають перевагу вину (рис. 1). При чому 25 \% відповіло, що не вживає спиртних напоїв.

Фвино

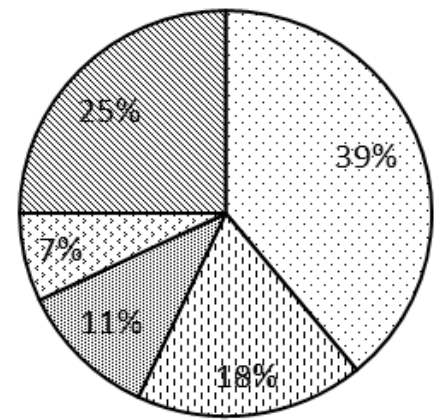

凹 водка, віскі, текіла

圈 лікери

曰коньяк, бренді

$\mathbb{8}$ не споживаю спиртних напоїв

Рис. 1. Розподіл за видами спиртних напоїв*

*побудовано авторами за даними анкетування

Однак не зважаючи на те, що вино полюблять 39 \% опитаних, на питання «Чи цікаво було би Вам, відвідуючи ресторан чи готель, потрапити на дегустацію одеських вин» стверджувально відповіло 64,3 \% (рис. 2). Тобто навіть люди, що не віддають перевагу вину, зацікавлені його скуштувати.

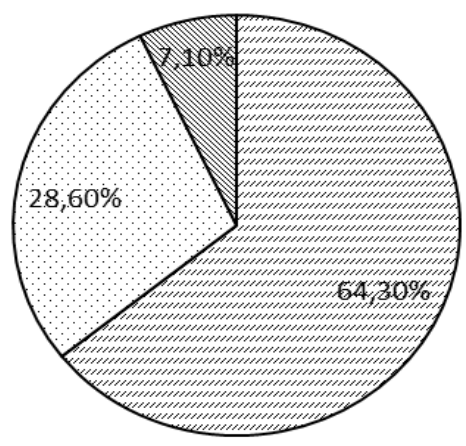

๒так

$\square$ можливо

$\mathbb{\mathbb { H }} \mathrm{\text {i }}$

Рис. 2. Розподіл за зацікавленістю у відвіданні дегустації одеських вин*

*побудовано авторами за даними анкетування

На питання «Чи знаєте Ви вина, що виробляються на території Одеської області?» стверджувальну відповідь надали 64,3 \% опитуваних (рис. 3 ). Торговельні марки одеських вин, що знають опитувані: «Колоніст», «Шабо», «Vila Tinta», «Французький бульвар», «Таїровські вина», «Вина Гулієвих». Тобто всі великі виробники були згадані анкетованими. В торговельні марки одеських виробників вин були записані ТМ «Коблево», що відноситься до Миколаїв- ської області, ТМ «Шустов», яка не випускає вино, а спеціалізується на коньяках. Жоден з опитуваних не перерахував більше трьох ТМ вин. Тому можна зробити висновок, що потенційна аудиторія не дуже гарно володіє інформацією про виробників одеських вин, їх особливості, зовсім відсутня інформація про гаражних виробників вин. Тому, на наш погляд, ніша одеських вин буде цікавою і дещо новою для пересічного відвідувача. 


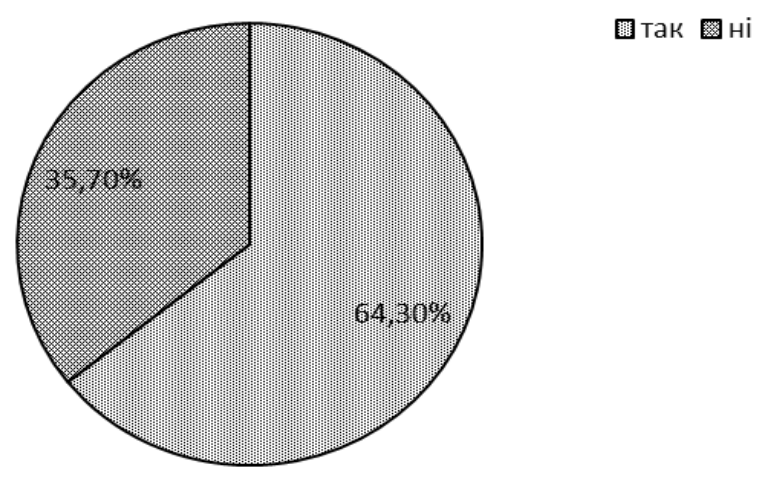

Рис. 3. Розподіл за знайомством з одеськими винами* *побудовано авторами за даними анкетування

Щодо кількості чоловік у дегустаційній групі було отримано однакову кількість відповідей, які від- дають перевагу індивідуальним дегустаціям на 2-3 чоловіка та невеликим групам на 4-9 чоловік (рис. 4).

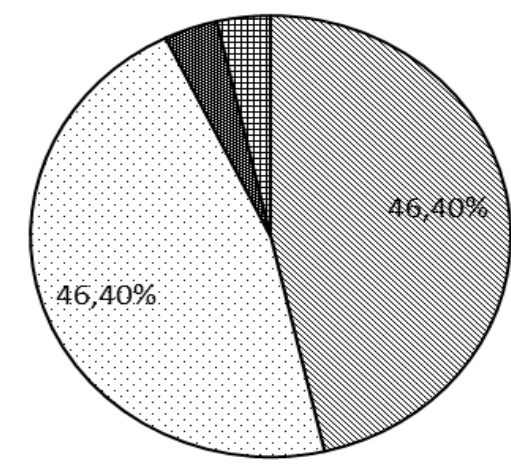

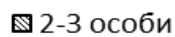

๑4-5 осіб

10-15 осі6

田 16 і більше

Рис. 4. Розподіл відповідей за кількістю осіб в дегустаційній групі*

*побудовано авторами за даними анкетування

За кількістю людей в групі вподобання розділились, але на нашу думку краще зробити залу на трохи більшу кількість відвідувачів, щоб можна було проводити додаткові заходи в приміщенні, наприклад, гастрономічні вечері, що розраховані на 10-12 чоловік.

Наступне питання торкалось тривалості про- ведення дегустації (рис. 5). Комфортною тривалістю для себе більшість опитуваних (35,7 \% та 28,6 \%) назвали 30 - 45 хвилин. Тільки 10,7 \% вважають, що дегустація може тривати менше 20 хвилин. Ще $25 \%$ вважають, що дегустація може тривати більше 45 хвилин.

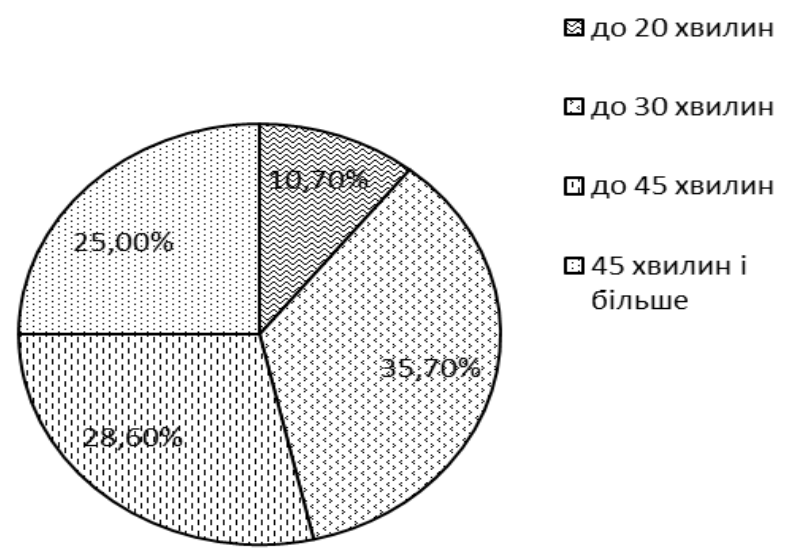

Рис. 5. Розподіл відповідей за тривалістю дегустації* *побудовано авторами за даними анкетування 
Більшість опитуваних (57,1 \%) вважають, що в дегустаційному залі повинно бути 3-4 сети з вином, ще 32,1 \% вважають, що кількість сетів повинна становити 5-6 (рис. 6).

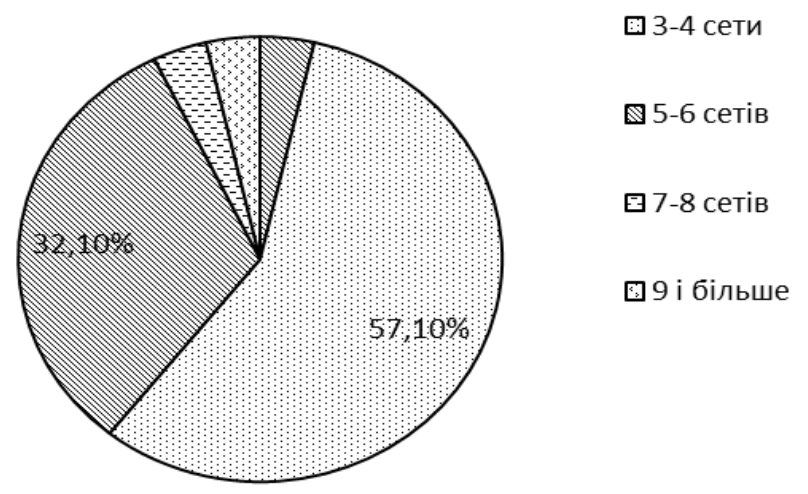
$\mathbb{8}$ не більше 2 сетів

문-4 сети

5-6 сетів

97-8 сетів

回9 і більше

\section{Рис. 6. Розподіл відповідей за кількістю сетів*}

*побудовано авторами за даними анкетування

На основі опитування робимо висновок, що на начальному етапі кількість сетів 3 винами в дегустаційному залі не повинна перевищувати 6. При подальшій роботі закладу можливо ця кількість буде зростати, або навпаки зменшиться.

Наступне питання ставило на меті дізнатись яка кількість вин у дегустаційному сеті повинна бути.
Більшість опитуваних (63 \%) вважає, що кількість вин не повинно перевищувати 3 найменувань, ще 18,5 \% вважають, що 4 (рис. 7). Тільки 14,8 \% опитуваних вважають, що кількість вин в сеті повинна бути не більше 5. При розробці винних сетів будемо опиратись на кількість 3-4 видів вина.

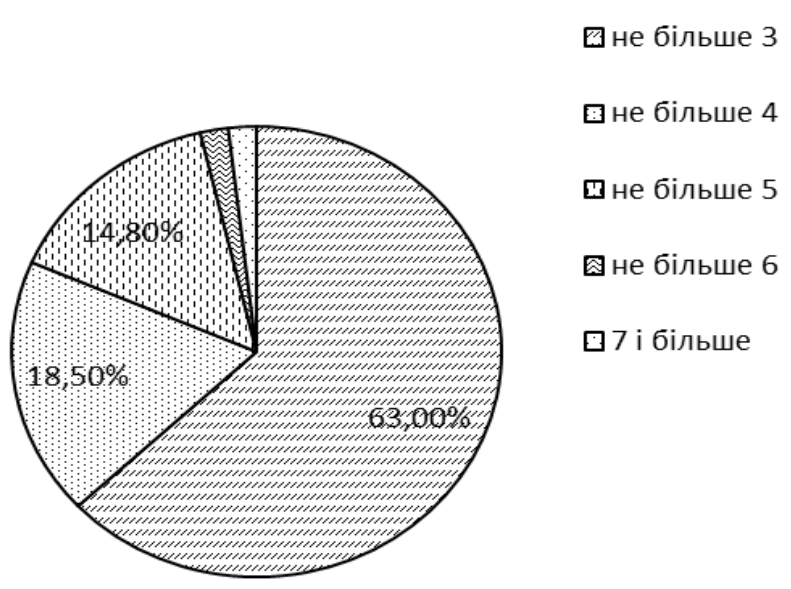

\section{Рис. 7. Розподіл відповідей за кількістю вин в сеті *}

*побудовано авторами за даними анкетування

Питання щодо прийнятної вартості дегустаційного сету, що складається з 4 вин отримало наступні відповіді (рис. 8): 199 грн.,

42,9 \% вважають прийнятною ціну від 100 до

28,6 \% вважають прийнятною ціну від 50 до 99 грн.,

10,7 \% - від 200 до 299 грн.

$10,7 \%$ - від 300 грн. і більше

7,1 \% вважають, що ціна за сет не повинна перевищувати 50 грн.
Згідно рис. 8. вартість сету з 4 вин не повинна перевищувати 200 грн. Враховуючи нижню ціну в 50 грн. за сет, вартість одного вина в дегустаційному сеті повинна бути в рамках від 12,5 до 50 грн. за дегустаційну порцію 58 мл.

Зацікавленість у купівлі після дегустації вина, що сподобалось, показало 67,9 \% опитуваних, ще 28,6\% можливо це зроблять (рис. 9). Тільки 3,5\% опитуваних відповіли категоричним «ні» на це питання. 


\section{궁 50 гривень}

曰50 - 99 гривень

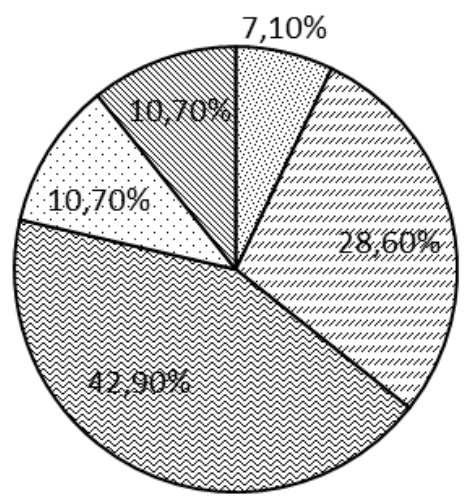

图100 - 199 гривень

$\square 200$ - 299 гривень

\$300 гривень і

більше

Рис. 8. Розподіл відповідей щодо вартості дегустаційного сету*

*побудовано авторами за даними анкетування

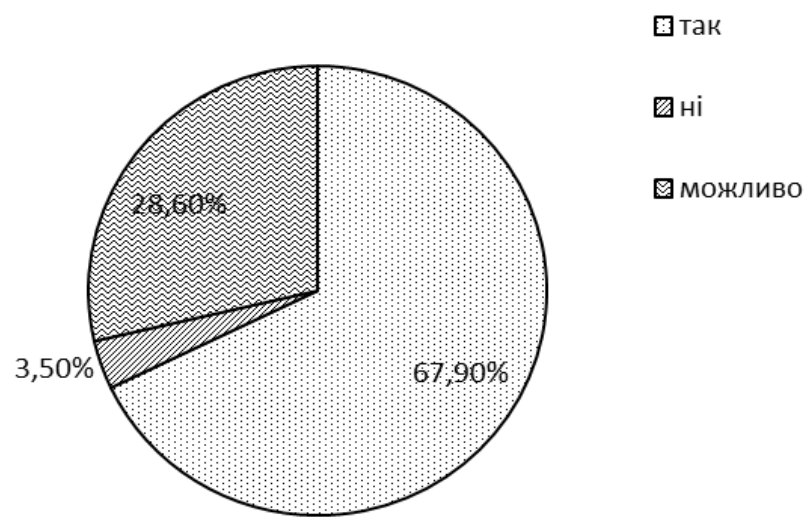

Рис. 9. Розподіл відповідей щодо зацікавленості у купівля вина після дегустації * *побудовано авторами за даними анкетування

Згідно рис. 9 більшість опитуваних зацікавлена в придбанні вина після дегустації, тому важливо створити винний бутік, де буде представлено вино одеського регіону. них (рис. 10)

Останнє питання стосувалось віка опитува-

圆до 21 року

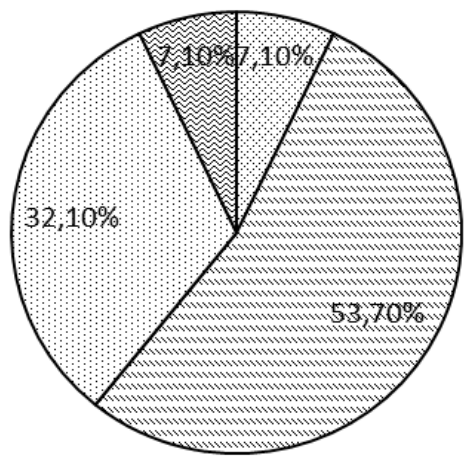

21-34 роки

군 49 років

图50 і більше

Рис. 10. Розподіл відповідей щодо віку опитуваних * *побудовано авторами за даними анкетування 
Відповіді розподілились наступним чином :

До 21 року - 7,1\%;

21-34 роки - 53,7\%;

$35-49$ роки - 32,1\%;

50 років і старше $-7,1 \%$.

Більшість опитуваних належить до вікової категорії від 21 до 34 років, друга по чисельності категорія - 35-49 років. Таким чином можна сказати, що більшість опитуваних 85,8 \% належать до активної вікової категорії, яка цікавиться вином.

Для того, щоб розробити конкурентоспроможній дегустаційний зал, необхідно проаналізувати роботу вже існуючих залів в м. Одесу та розташовані поблизу міста.

Ціна на дегустації відрізняється у різних закладів і залежить від тривалості дегустації, кількості вин та їх цінової категорії. В середньому ціна одного дегустаційного бокалу коливається в рамках 20-70 грн. Найдорожчі дегустаційні сети у ТМ «Колоніст» (500 грн. за 8 позицій) та «Вина Гулієвих» (587 грн. за 7 позицій).

Контекстний аналіз відгуків дегустаційних залів Одеси та Одеської області (табл. 1) показав, що незадоволення у відвідувачів дегустацій викликає відсутність закуски, яку можна заказати до вина, окрім крекерів та горішків. Важливішим фактором, що відмічають про будь-який дегустаційний зал - це цікава та пізнавальна інформація від сомельє. Відвідувачам цікаво як характеристики вина, так й історичні данні, технологія виробництва вина, винний етикет, а також принципи доповнення смаку страв різними видами вин. Тому важливу увагу необхідно привернути при пошуку висококваліфікованого сомельє та працівника винного бутіку, що мають бути не тільки доброзичливими, але й мати великі пізнання у вині та мати почуття гумору.

Контекстний аналіз відгуків для дегустаційних залів *

Таблиця 1

\begin{tabular}{|c|c|c|}
\hline \\
\hline Назва залу & Позитивні відгуки & Негативні відгуки \\
\hline $\begin{array}{l}\text { Дегустаційний зал } \\
\text { Масандровських } \\
\text { вин. Одеса }\end{array}$ & $\begin{array}{l}\text { Цікава інформація від сомельє } \\
\text { Наявність унікальних вин в тому числі ви- } \\
\text { на півдня України } \\
\text { Широка цінова категорія } \\
\text { Проводиться коротка характеристика вин } \\
\text { Чудове обслуговування } \\
\text { Зручне розташування }\end{array}$ & $\begin{array}{l}\text { Вина занадто дорогі } \\
\text { Багато іноземного вина }\end{array}$ \\
\hline $\begin{array}{l}\text { Дегустаційний зал } \\
\text { IBiB ім.Таїрова }\end{array}$ & $\begin{array}{l}\text { Цікава інформація в тому числі про винний } \\
\text { етикет } \\
\text { Велика кількість вина на дегустації } \\
\text { Індивідуальній підхід }\end{array}$ & $\begin{array}{l}\text { Важко купити вина поза територією ін- } \\
\text { ституту } \\
\text { Відсутня закуска окрім крекерів }\end{array}$ \\
\hline $\begin{array}{l}\text { Одеський завод } \\
\text { шампанських вин }\end{array}$ & $\begin{array}{l}\text { Гарна робота сомельє } \\
\text { Вичерпні консультації } 3 \text { будь-якого сорту } \\
\text { вина }\end{array}$ & Красива історична будівля \\
\hline Шабо & $\begin{array}{l}\text { Цікава та пізнавальна інформація в тому } \\
\text { числі про винний етикет } \\
\text { Приємний персонал фірмового магазину } 3 \\
\text { почуттям гумору } \\
\text { Чистота, красота, затишок та комфорт }\end{array}$ & $\begin{array}{l}\text { Вино у фірмовому магазині дорожче, ніж } \\
\text { в звичайному супермаркеті. } \\
\text { Великі екскурсійні групи буває тісно та } \\
\text { шумно } \\
\text { Допускають дітей 3-6 років на екскурсію } \\
\text { та дегустацію. } \\
\text { Відсутня закуска окрім крекерів }\end{array}$ \\
\hline $\begin{array}{l}\text { Enoteca Old Oak } \\
\text { Винний клуб «Bi- } \\
\text { нтаж» }\end{array}$ & $\begin{array}{l}\text { Великий вибір вин, широко представлені } \\
\text { місцеві виробники } \\
\text { Помірні ціни } \\
\text { Додатково є м'ясні та сирні делікатеси } \\
\text { Дуже люб'язне обслуговування } \\
\text { Приємний інтер'єр }\end{array}$ & Не відзначено негативу \\
\hline
\end{tabular}

* Власна розробка авторів

Під час проведення «мозкового штурму» було запропоновано до впровадження багато варіантів додаткових послуг для дегустаційного залу. Результати мозкового штурму наведено в табл. 2.

На основі проведеного мозкового штурму пропонуємо до впровадження наступні додаткові послуги для дегустаційного залу при готелі «Атлантік»:

1. Підбір ексклюзивних спеціальних сетів вин та проведення різних видів дегустації за замовленням - сліпа, комбінація вина і їжі, сортова дегустація, вертикальна дегустація.
2. Продаж подарункових карт на проведення індивідуальних дегустацій.

3. Організація гастрономічних вечорів із застосуванням вин одеського регіону.

4. Запрошення відомих сомельє

5. Організація приватних винних вечірок.

6. Проведення винних семінарів та тімбілдінгів.

7. Продаж вина, виробленого в одеському регіоні, в тому числі подарункових наборів вин.

8. Організація івентів з метою презентації різних винних виробників. 
Таблиця 2

Мозковий штурм щодо додаткових послуг дегустаційного залу *

\begin{tabular}{|c|c|c|c|}
\hline $\begin{array}{c}\text { Назва додаткової } \\
\text { послуги }\end{array}$ & Переваги послуги & Недоліки послуги & $\begin{array}{c}\text { Відмітка про } \\
\text { рекомендацію } \\
\text { до впрова- } \\
\text { дження }\end{array}$ \\
\hline Продаж вина & $\begin{array}{l}\text { Попит підтверджено опитуван- } \\
\text { ням, додатковий прибуток, на- } \\
\text { явність вільного приміщення }\end{array}$ & $\begin{array}{l}\text { Додатковий персонал, додаткові } \\
\text { площі }\end{array}$ & + \\
\hline $\begin{array}{l}\text { Продаж дегустаційних } \\
\text { бокалів та винних аксе- } \\
\text { суарів }\end{array}$ & Додатковий прибуток & $\begin{array}{l}\text { Збільшення асортиментної лінії, } \\
\text { необхідні додаткові площі для } \\
\text { зберігання, можливий бій скла }\end{array}$ & - \\
\hline $\begin{array}{l}\text { Продаж подарункових } \\
\text { наборів вин }\end{array}$ & $\begin{array}{l}\text { Не потребує додаткових фі- } \\
\text { нансових витрат окрім додат- } \\
\text { кового пакування }\end{array}$ & Додаткове пакування & + \\
\hline $\begin{array}{l}\text { Підбір ексклюзивних } \\
\text { спеціальних сетів вин }\end{array}$ & $\begin{array}{l}\text { Не потребує додаткових фі- } \\
\text { нансових витрат }\end{array}$ & Висока кваліфікація сомельє & + \\
\hline $\begin{array}{l}\text { Організація лекцій про } \\
\text { історію виноробства, у } \\
\text { тому числі на Одещині }\end{array}$ & Цікаво для поціновувачів вина & $\begin{array}{l}\text { Додатковий персонал, може не } \\
\text { мати попиту як окремий захід }\end{array}$ & - \\
\hline $\begin{array}{l}\text { Організація гастроно- } \\
\text { мічних вечерь }\end{array}$ & $\begin{array}{l}\text { Не потребує додаткових фі- } \\
\text { нансових витрат }\end{array}$ & $\begin{array}{l}\text { Потребує додаткового часу со- } \\
\text { мельє та шеф-кухаря для підго- } \\
\text { товки }\end{array}$ & + \\
\hline $\begin{array}{l}\text { Гастрономічні фести- } \\
\text { валі за участі місцевих } \\
\text { жителів на території } \\
\text { комплексу }\end{array}$ & $\begin{array}{l}\text { PR- захід для просування не } \\
\text { лише залу, але й комплексу } \\
\text { взагалі }\end{array}$ & $\begin{array}{l}\text { Великі додаткові кошти, додат- } \\
\text { кові робітники }\end{array}$ & - \\
\hline $\begin{array}{l}\text { Продаж подарункових } \\
\text { карт на дегустацію }\end{array}$ & $\begin{array}{l}\text { Невеликі додаткові витрати } \\
\text { на друк карток }\end{array}$ & $\begin{array}{l}\text { Не перевірено попит на дану } \\
\text { послугу }\end{array}$ & + \\
\hline Організація концертів & $\begin{array}{l}\text { Цікавий захід для поціновува- } \\
\text { чів вина та музики }\end{array}$ & $\begin{array}{l}\text { Додаткові площі, залучення му- } \\
\text { зикантів за окрему платню }\end{array}$ & - \\
\hline $\begin{array}{l}\text { Продаж абонементів на } \\
\text { відвідування дегустацій }\end{array}$ & $\begin{array}{l}\text { Невеликі додаткові витрати } \\
\text { на друк сертифікатів та вне- } \\
\text { сення змін у автоматизовану } \\
\text { систему обліку ресторану }\end{array}$ & $\begin{array}{l}\text { Не перевірено попит на дану } \\
\text { послугу }\end{array}$ & + \\
\hline $\begin{array}{l}\text { Проведення кіно- } \\
\text { вечорів } 3 \text { дегустацією } \\
\text { вина }\end{array}$ & $\begin{array}{l}\text { Цікавий захід для кіноманів, } \\
\text { що полюбляють невеликі зали }\end{array}$ & $\begin{array}{l}\text { Додаткове обладнання, питання } \\
3 \text { ліцензією на показ фільмів }\end{array}$ & - \\
\hline $\begin{array}{l}\text { Запрошення відомих } \\
\text { сомельє }\end{array}$ & $\begin{array}{l}\text { Привабливий привід для по- } \\
\text { ціновувачів вина, можливість } \\
\text { отримати новий досвід }\end{array}$ & $\begin{array}{l}\text { Додаткові витрати на оплату } \\
\text { сомельє }\end{array}$ & + \\
\hline $\begin{array}{l}\text { Проведення літератур- } \\
\text { них вечорів }\end{array}$ & $\begin{array}{l}\text { Цікавий захід для поціновува- } \\
\text { чів вина та літератури }\end{array}$ & $\begin{array}{l}\text { Не перевірено попит на дану } \\
\text { послугу }\end{array}$ & - \\
\hline $\begin{array}{l}\text { Організація приватних } \\
\text { винних вечірок }\end{array}$ & $\begin{array}{l}\text { Урізноманітнення дозвілля } \\
\text { гостей, невеликі витрати на } \\
\text { організацію вечірки }\end{array}$ & $\begin{array}{l}\text { Потребує додаткового часу для } \\
\text { організації }\end{array}$ & + \\
\hline Проведення вікторини & $\begin{array}{l}\text { Урізноманітнення дозвілля } \\
\text { гостей }\end{array}$ & $\begin{array}{l}\text { Потребує додаткові площі та } \\
\text { додаткових людей для організа- } \\
\text { ції вікторини }\end{array}$ & - \\
\hline Проведення квестів & $\begin{array}{l}\text { Урізноманітнення дозвілля } \\
\text { гостей }\end{array}$ & $\begin{array}{l}\text { Потребує залучення додаткового } \\
\text { персоналу з організації квестів }\end{array}$ & - \\
\hline $\begin{array}{l}\text { Проведення винних } \\
\text { семінарів }\end{array}$ & $\begin{array}{l}\text { Залучення корпоративних } \\
\text { клієнтів, додатковий прибуток }\end{array}$ & $\begin{array}{l}\text { Використання додаткових при- } \\
\text { міщень конференц-залів }\end{array}$ & + \\
\hline $\begin{array}{l}\text { Проведення винних } \\
\text { тімбілдінгів }\end{array}$ & $\begin{array}{l}\text { Залучення корпоративних } \\
\text { клієнтів, додатковий прибуток }\end{array}$ & $\begin{array}{l}\text { Додаткове навантаження на со- } \\
\text { мельє }\end{array}$ & + \\
\hline $\begin{array}{l}\text { Проведення вечорів } \\
\text { настільних ігор }\end{array}$ & $\begin{array}{l}\text { Урізноманітнення дозвілля } \\
\text { гостей }\end{array}$ & $\begin{array}{l}\text { Потребує додаткових приміщень } \\
\text { та витрати на закупівлю ігор }\end{array}$ & - \\
\hline $\begin{array}{l}\text { Проведення інтелекту- } \\
\text { альних ігор типа «Що? } \\
\text { Де? Коли?» та «Квіз» }\end{array}$ & $\begin{array}{l}\text { Урізноманітнення дозвілля } \\
\text { гостей }\end{array}$ & $\begin{array}{l}\text { Потребує залучення додаткового } \\
\text { персоналу з організації ігор та } \\
\text { додаткових приміщень }\end{array}$ & - \\
\hline
\end{tabular}




\begin{tabular}{|c|c|c|c|}
\hline \multicolumn{4}{|c|}{ Продовження табл.2 } \\
\hline $\begin{array}{c}\text { Назва додаткової } \\
\text { послуги }\end{array}$ & Переваги послуги & Недоліки послуги & $\begin{array}{l}\text { Відмітка про } \\
\text { рекомендацію } \\
\text { до впрова- } \\
\text { дження }\end{array}$ \\
\hline $\begin{array}{l}\text { Організація івентів } 3 \\
\text { метою презентації різ- } \\
\text { них винних виробників }\end{array}$ & $\begin{array}{l}\text { Знайомство } 3 \text { новими зразка- } \\
\text { ми вин, надання площі для } \\
\text { оренди }\end{array}$ & $\begin{array}{l}\text { Кошти на оренду можуть входи- } \\
\text { ти до знижки при придбанні ви- } \\
\text { на }\end{array}$ & 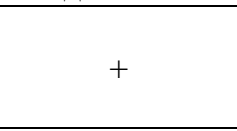 \\
\hline $\begin{array}{l}\text { Організація морських } \\
\text { прогулянок } 3 \text { вином }\end{array}$ & $\begin{array}{l}\text { Урізноманітнення дозвілля } \\
\text { гостей }\end{array}$ & $\begin{array}{l}\text { Додаткові кошти на оренду ка- } \\
\text { теру, сезонність послуги, важко } \\
\text { передбачити завантаження кате- } \\
\text { ру }\end{array}$ & - \\
\hline
\end{tabular}

\section{* Власна розробка авторів}

Всі ці додаткові послуги будуть впроваджуватися поступово, по мірі матеріальних та кадрових можливостей. Організація першочергових, найцікавіших, нових і конкурентоспроможних послуг при готелі «Атлантік» - це створення дегустаційного залу та винного бутіку, так як вони представляють собою туристичний об'єкт в контексті винного туризму i одночасно можуть стати цікавим закладом для одеситів.

Вивчивши всі проблеми, взявши до уваги результати всіх досліджень і урахувавши побажання респондентів було розроблено 6 винних сетів одеських вин для функціонування дегустаційного залу, що наведені у табл.3.

Таблиця 3

\section{Винні дегустаційні сети*}

\begin{tabular}{|c|c|}
\hline Назва сету & Перелік вин \\
\hline $\begin{array}{l}\text { Одеський } \\
\text { чорний }\end{array}$ & $\begin{array}{l}\text { «Одеський чорний» сухе червоне вино ТМ «Таїрово» } 2018 \\
\text { «Одеський чорний» сухе червоне вино ТМ «Колоніст» } 2018 \\
\text { «Одеський чорний» сухе червоне вино ТМ «Villa Tinta» } 2017 \\
\text { Гужери }\end{array}$ \\
\hline $\begin{array}{l}\text { Каберне } \\
\text { Совіньон: }\end{array}$ & $\begin{array}{l}\text { «Cabernet Rose» сухе рожеве вино TM «Bolgrad» } \\
\text { Каберне «Болградський резерв» сухе червоне вино ТМ «Болградський виноробний завод» } \\
\text { «Каберне» сухе червоне вино ТМ «Villa Tinta» } 2017 \\
\text { «Сabernet Reserve» сухе червоне вино TM «Вина Гулієвих» } \\
\text { Гужери }\end{array}$ \\
\hline Шардоне & $\begin{array}{l}\text { «Chardonnay» cухе ординарне біле вино ТМ «Bolgrad» } \\
\text { «Chardonnay Reserve» сухе сортове витримане біле вино ТМ «Вина Гулієвих» } 2016 \\
\text { «Chardonnay Reserve» сухе сортове витримане біле вино ТМ «Shabo» } \\
\text { Шардоне «Висока гамма» сухе сортове витримане біле вино TM «Колоніст» } 2018 \\
\text { Грінки пшеничні }\end{array}$ \\
\hline Мускат & $\begin{array}{l}\text { «Мускат Милосердя» напівсолодке десертне біле вино ТМ «Таїрово» } \\
\text { «Muscat Reserve» десертне біле вино «ТМ Shabo» } \\
\text { «Muscat Select Rouge» напівсолодке червоне вино TM «Bolgrad» } \\
\text { Крекер }\end{array}$ \\
\hline Ігристе & $\begin{array}{l}\text { «Rose Brut» ігристе брют рожеве вино ТМ «Bolgrad» } \\
\text { “Брют рожеве Shabo Classic” ігристе витримане брют рожеве вино «ТМ Shabo» } \\
\text { «Дольче Віта» ігристе напівсолодке рожеве вино ТМ «Таїрово» } \\
\text { «Тіntarella Rose Jardin» ігристе напівсолодке рожеве вино TM «Villa Tinta» } \\
\text { Брауні }\end{array}$ \\
\hline $\begin{array}{l}\text { Одеський } \\
\text { ексклюзив }\end{array}$ & $\begin{array}{l}\text { «Telti-Kuruk Reserve» сухе біле вино «ТМ Shabo» } \\
\text { «Сухолиманське» сухе біле сортове вино TM «Колоніст» } 2018 \\
\text { «Wite Puzzle» сухе біле вино TM «Don Alejandro Winery» (шардоне, аліготе, мускат Голодри- } \\
\text { ги, рислінг } 15 \text { і } 16 \text { рік) } \\
\text { Грісіні }\end{array}$ \\
\hline
\end{tabular}

* Власна розробка авторів

Проведена оцінка інвестиційної привабливості проекту створення дегустаційного залу з винним бутіком при готелі «Атлантік» показала, що інвестиційний проект $\epsilon$ досить привабливим. Інвестиції, що потрібні на реконструкцію двох приміщень, закупів- лю обладнання та на обігові активи складають біля 870 тис. грн. Оскільки чистий приведений дохід проекту складає 262,61 тис. грн., що більше ніж нуль, індекс дохідності проекту більш 1, та складає 1,3, термін окупності інвестицій 10 місяців, що теж $\epsilon$ 
привабливим за нормативом, то можна сказати, що створення дегустаційного залу при готелі «Атлантік» $\epsilon$ економічно доцільним.

Висновки та перспективи подальших досліджень. За результатами проведених досліджень можна зробити ряд висновків:

1. На Одещині активно розвивається виноробство, розширюють свій асортимент великі виноробні заводи, починають відкриватись багато невеличких гаражних виробництв. При цьому якість вин, що виробляється в Одеському регіоні, підтверджена багатьма міжнародними конкурсами, але населення не дуже поінформоване положенням справ в галузі виноробства.

2. Розвивається культура споживання вина, з'являється зацікавленість у нових смаках та сортах вина, що підтверджується створенням винних барів та ресторанів, а також активним розвитком винного туризму та дегустаційних залів.

3. Дегустаційні зали Одеси, представлені в основному на підприємствах, що виробляють вина, тобто в залі найчастіше продегустувати можна тільки вина одного виробника. Але цікавими є моносортові дегустації, коли вино вироблено з одного сорту винограду, але різними виробниками. В моносортовій дегустації можна порівнювати якість вин різних виробників. Такі дегустації пропонують лише декілька залів в Одесі і винний клуб «Вінтаж».

4. Для проектування додаткових послуг дегустаційного залу, розташованого на підприємстві індустрії гостинності доцільно використовувати метод анкетування, контекстний аналіз відгуків, мозковий штурм 3 урахуванням аналізу ресурсів закладу готельно-ресторанного бізнесу. Ці дослідження дозволяють обрати серед великого переліку додаткових послуг саме такий асортимент, що може впроваджуватись в роботу конкретного закладу та приносити максимальний прибуток за рахунок розширення сервісних послуг.

5. Розрахунки економічних показників інвестиційної привабливості дають позитивну оцінку доцільності створення дегустаційного залу при готелі «Атлантік».

\section{Література}

1. Ford R.C., Sturman M.C., Heaton C.P. Managing quality service in hospitality - The Hospitality Service Strategy. New York: Delmar $\quad$ Cengage 2012. URL: https://nscpolteksby.ac.id/ebook/files/Ebook/Hospitality/Managing\%20Quality\%20Service\%20in\%20Hospitality $\% 20 \% 282011 \% 29 / 7 . \% 20$ Section $\% 201 \% 20$ Chapter\%201\%20The\%20Basics\%20of\%20Wow\%20-

\%20The\%20Guest\%20Knows\%20Best.pdf (viewed on: 11.07.2021).

2. Kotler P. Marketing Management: Analysis Planning, Implementation and Control. 9th Edition. Prentice Hall College Inc., 1999.

3. Bretthauer K.M. Service management // Decision Sciences. 2004. № 3, Vol. 35. P. 325-332. doi: 10.1111/j.0011-7315.2004.35031.x

4. Ford R.C., Heaton C.P., Brown, S.W. Delivering excellent service: Lessons from the best firms // California Management Review. 2001. № 1, Vol. 44. P. 39-56. doi: 10.2307/41166110

5. Романенко О.О. Особливості використання комплексу маркетингу та його концепцій на підприємствах готельного господарства. Наук. пр. // Збірник наукових праць Національного університету державної податкової служби України. 2011. № 1. С. 490-494.

6. Шаповалова О. М., Козьякова С. С. Аналіз інноваційної діяльності у сфері послуг на прикладі готельного господарства // Інвестиції: практика та досвід. 2013. № 17. С. 70-74.

7. Троян А.В. Особливості асортиментної політики підприємства в сучасних умовах господарювання // Ефективна економіка. 2014. № 1. URL: http://www.economy.nayka.com.ua/?op=1\&z=2708. (дата звернення: 11.07.2021).

8. Shapiro M., Gómez M. Customer satisfaction and sales performance in wine tasting rooms // International Journal of Wine Business Research. 2014. № 1, Vol. 26. P. 45-60. doi: 10.1108/IJWBR-09-2012-0026

9. Miguel G. Increasing Customer Satisfaction Improves Tasting Room Sales. Research Focus // Cornell Viticulture and Enology. 2010. № 3. P. 1-6.

10. Haverila M., Haverila, K., Arora M. Comparing the service experience of satisfied and non-satisfied customers in the context of wine tasting rooms using the SERVQUAL model // International Journal of Wine Business Research. 2020. № 2, Vol. 32. P. 301-324. doi: 10.1108/IJWBR-12-2018-0070

11. Привабливість туристичного та дегустаційного бізнесу Одеської області: монографія / Калмикова І.С. та ін.; за заг. ред. Меліх О.О. Київ: ХАМЕЛЕОН К, 2018. 137 с.

12. Ряшко Г.М., Асауленко Н.В., Новічкова Т.П. Удосконалення сервісу на підприємствах індустрії гостинності шляхом проектування дегустаційних залів // Економіка харчової промисловості. 2021. Т.13, вип. 1. С. 75-81. doi: 10.15673/fie.v13i1.2004

13. Винний та гастрономічний туризм: глобальні тренди та локальні практики: монографія / Басюк Д.І. та ін.; за ред. Басюк Д.І. Вінниця: ПП ТД "Едельвейс і К", 2017. 316 с.

14. Осипова Л.А. Калмикова І.С., Меліх О.О. Економічна ефективність дегустаційної діяльності у складі туристичного бізнесу // Зб. тез доп. 77-ої наук. конф. викл. акад., Одеса, 18-21 квіт. 2017 р. / Одес. нац. акад. харч. технологій. Одеса, 2017. С. 170-171. 


\author{
Riashko H. \\ PhD., Associate Professor \\ Department of Hotel and Restaurant Business \\ E-mail: rina257@gmail.com \\ ORCID: 0000-0002-6237-7263 \\ Novichkova T. \\ PhD., Associate Professor \\ Department of Hotel and Restaurant Business \\ E-mail: tamarakoled@gmail.com \\ ORCID ID: 0000-0001-6133-9882
}

\author{
Asaulenko N. \\ Assistant \\ Department of Hotel and Restaurant Business \\ E-mail:nataliya.asaulenko@ukr.net \\ ORCID: 0000-0001-7057-4614 \\ Novichkov V. \\ PhD., Associate Professor \\ Department of Hotel and Restaurant Business \\ Odessa National Academy of Food Technologies \\ Kanatna str., 112, Odesa, Ukraine, 65039 \\ E-mail: vicnov@ukr.net \\ ORCID ID: 0000-0001-9720-8163
}

\section{SERVICE DESIGN OF TASTING ROOMS AS A STRATEGIC VECTOR OF SERVICE DEVELOPMENT IN THE HOSPITALITY INDUSTRY}

The article examines various approaches to finding innovations for creating a tasting room and designing an assortment of additional services based on it. A tasting room created separately from production has a number of advantages. It can become a location for promoting brands of regional manufacturers. Tasting, which is carried out according to the rules, improves the culture of wine consumption, increases knowledge about the tasting product, and also informs about its manufacturer. The Odessa region is characterized by an active development of the wine industry, including an increase in garage production. Despite the increasing interest in wine tourism, the population does not have sufficient information about the majority of Odessa producers. To compare the quality of wines from different manufacturers, it is necessary to carry out single-varietal tastings, which are not possible in tasting rooms located at wineries. Designing the range of services for a tasting room as part of the hospitality industry enterprises, it is advisable to carry out contextual analysis of reviews and brainstorming, using questionnaires, taking into account the resources of the hotel and restaurant business. Such studies allow you to select a range of services that can be implemented in the work of a particular enterprise and bring maximum profit. The main services of the tasting room at the enterprises of the hospitality industry may include: the sale of products and related products, the development of exclusive tasting sets, the organization of gastronomic evenings, thematic seminars and parties, the organization of gastronomic tours and off-site tastings. As an example, a study is given on the design of additional services when creating a tasting room at the Atlantic Hotel.

Key words: hospitality industry, service, design, tasting room, hospitality industry enterprises.

\section{References}

1. Ford, R. C., Sturman, M.C., \& Heaton, C. P. (2012). Managing quality service in hospitality - The Hospitality Service Strategy. New York: Delmar Cengage Learning. Retrieved July 11, 2021, from https://nscpolteksby.ac.id/ebook/files/Ebook/Hospitality/Managing\%20Quality\%20Service\%20in\%20Hospitality\%20\% $282011 \% 29 / 7 . \% 20$ Section\%201\%20Chapter\%201\%20The\%20Basics\%20of\%20Wow\%20-

$\% 20$ The\%20Guest\%20Knows\%20Best.pdf

2. Kotler, P. (1999). Marketing Management: Analysis Planning, Implementation and Control (9th ed.). Prentice Hall College Inc.

3. Bretthauer, K. M. (2004). Service management. Decision Sciences, 35(3), 325-332. doi: 10.1111/j.00117315.2004.35031.x

4. Ford, R. C., Heaton, C. P., \& Brown, S. W. (2001). Delivering excellent service: Lessons from the best firms. California Management Review, 44(1), 39-56. doi: 10.2307/41166110

5. Romanenko, O. O. (2011). Osoblyvosti vykorystannia kompleksu marketynhu ta yoho kontseptsii na pidpryiemstvakh hotelnoho hospodarstva. Zbirnyk naukovykh prats Natsionalnoho universytetu derzhavnoi podatkovoi sluzhby Ukrainy, (1), 490-494.

6. Shapovalova, O. M., \& Koziakova, S. S. (2013). Analiz innovatsiinoi diialnosti u sferi posluh na prykladi hotelnoho hospodarstva. Investytsii: praktyka ta dosvid, (17), 70-74.

7. Troian, A. V. (2014). Osoblyvosti asortymentnoi polityky pidpryiemstva v suchasnykh umovakh hospodariuvannia. Efektyvna ekonomika, (1). Retrieved July 11, 2021, from http://www.economy.nayka.com.ua/?op=1\&z=2708

8. Shapiro, M., \& Gómez, M. (2014). Customer satisfaction and sales performance in wine tasting rooms. International Journal of Wine Business Research, 26(1), 45-60. doi: 10.1108/IJWBR-09-2012-0026 
9. Miguel, G. (2010). Increasing Customer Satisfaction Improves Tasting Room Sales. Research Focus. Cornell Viticulture and Enology, (3), 1-6.

10. Haverila, M., Haverila, K., \& Arora, M. (2020). Comparing the service experience of satisfied and nonsatisfied customers in the context of wine tasting rooms using the SERVQUAL model. International Journal of Wine Business Research, 32(2), 301-324. doi: 10.1108/IJWBR-12-2018-0070

11. Kalmykova, I. S. (2018). Pryvablyvist turystychnoho ta dehustatsiinoho biznesu Odeskoi oblasti. (O. O. Melikh, Ed.). KhAMELEON K.

12. Riashko, H. M., Asaulenko, N. V., \& Novichkova, T. P. (2021). Udoskonalennia servisu na pidpryiemstvakh industrii hostynnosti shliakhom proektuvannia dehustatsiinykh zaliv. Ekonomika kharchovoi promyslovosti, 13(1), 75-81. doi: 10.15673/fie.v13i1.2004

13. Basiuk, D. I. (2017). Vynnyi ta hastronomichnyi turyzm: hlobalni trendy ta lokalni praktyky (Basiuk D. I., Ed.). PP TD "Edelveis i K".

14. Osypova, L. A., Kalmykova, I. S., \& Melikh, O. O. (2017). Ekonomichna efektyvnist dehustatsiinoi diialnosti u skladi turystychnoho biznesu. In Zb. tez dop. 77-oi nauk. konf. vykl. akad. (pp. 170-171). Odesa (18-21.04.2017); Odes. nats. akad. kharch. tekhnolohii.

Received 25 July 2021

Approved 8 August 2021 Available in Internet 24.10.21

Цитування згідно ДСТУ 8302:2015

Ряшко Г.М., Асауленко Н.В., Новічкова Т.П., Новічков В. К. Проектування послуг дегустаційних залів як стратегічний вектор розвитку сервісу в індустрії гостинності // Економіка харчової промисловості. 2021. Т.13, вип. 3. C. 76-87. doi: 10.15673/fie.v13i3.2135

Cite as APA style citation

Riashko, H., Asaulenko, N., Novichkova, T., \& Novichkov, V. (2021). Service design of tasting rooms as a strategic vector of service development in the hospitality industry. Food Industry Economics, 13(3), 76-87. doi: 10.15673/fie.v13i3.2135 